\title{
OBITUARIES
}

\section{Baron Joji Sakurai}

$\mathrm{O}^{\mathrm{N}}$ January 28 of this year there passed away from this world, at the ripe age of eighty years, Prof. Baron Joji Sakurai, the great promoter of scientific research in Japan, ardent lover of peace and friendship among men, and one of the finest spirits and greatest gentlemen of this or any age. Proud indeed must be his homeland to have produced one who was honoured, respected, and beloved by men of science of many nations, and proud are we in England to have had him in our care during his formative years of study at University College, London (1876-1881). No one who had the privilege of meeting him ever failed to bo deeply impressed and strongly attracted by his quiot dignity, his gentlo and endearing modesty, and the warm glow of friendliness and high in. telligence that shone from his oyes and suffused his every word. Throughout a long and laborious lifo he strovo with a total disregard of self to make his fellow-countrymen strong and healthy in mind and body by the light of reason and science, to promoto their peaceful, cultural relations with men of other lands, and to build up an amity of nations, founded on mutual co-operation directed to tho high goal of a civilization, purified from ignoranco and proju. dico and illumined by a
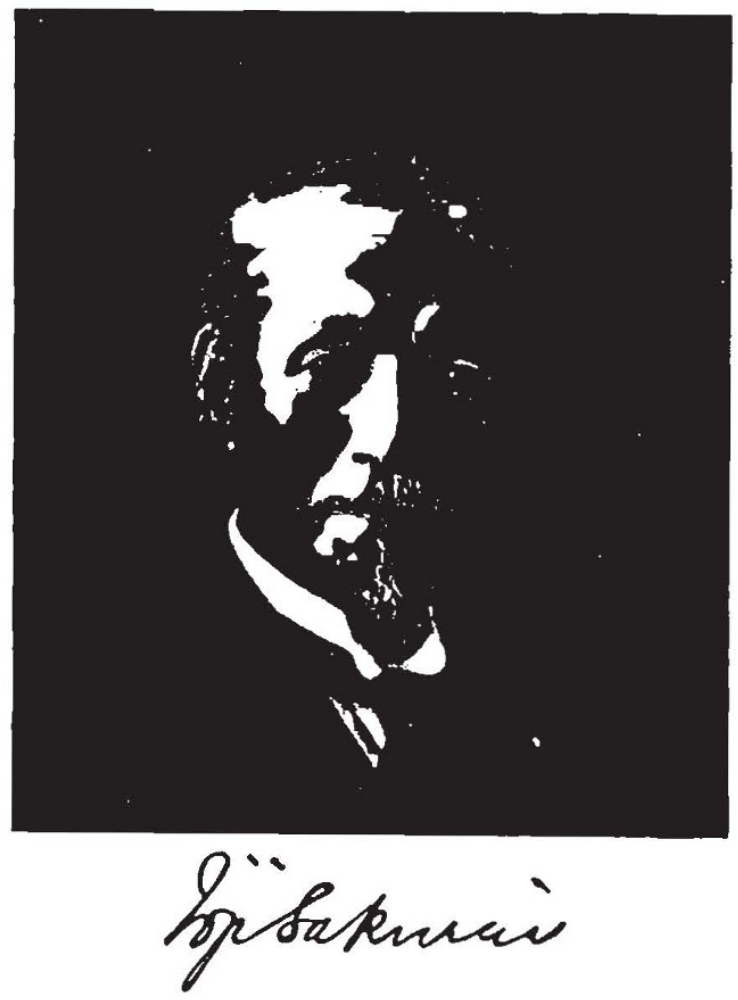

October of that year. He studied chemistry under Prof. Williamson, physics under Prof. Caroy Foster and Dr. Oliver J Jodge, mineralogy under Prof. G. Morris, and hygieno under Prof. W. H. Corfield. At the end of his first year ho won the gold medal for chemistry, and a year later the Clothworkers' Scholarship for proficiency in chemistry and physics. Under the guidance of Williamson, Sakurai began an interesting research on metallic compounds containing bivalent hydrocarbon radicals, which was continued after his return to Japan and resulted in three papers communicated to the Journal of the Chemical Society in the years 1880,1881 , and 1882. In 1885 ho obtained methylene chloro. iodide, a sign that his interest in organic chem. istry still continued.

In September 1881 Sakurai returned to his nativo country and was immediately appointed lecturer in chemistry in the University of 'Tokyo. In the following year ho becamo professor at the early ago of trenty-four years. As time went on, he becamo deeply impressed with the importance of the new physical chemistry associated with the names of Raoult, I.e Chatelier, Arr. hénius, van't Hoff, Ostwald and Nernst. IBy his examplo and his teaching he excrcised a profound influence on the direction of chemical studies in Japan, and becamo indeed the great hope. So lived and died this great and good man that came from the East, and was the friend of all men of goodwill throughout the world.

Joji Sakurai was born in Kanazarva (Provinco of Kaga) on August 18, 1858. Ho went to Tokyo in 1871 and studied chemistry under R. W. Atkinson at the Kaisei Gakko, a forerunner of the University of Tokyo. At the request of the Japanese Government, Atkinson had been sent to teach chemistry at Tokyo by Prof. Alexander W. Williamson, of University College, London. Williamson had early interested himself in the welfare of Japan, especially in the education of young Japanese students in Fngland, among whom were the celebrated Prince Ito and Narquis Inoue. In 1876 young Sakurai was sent by his Government to prosecute the study of chemistry in England, and entered University College in founder of scientific chemistry in that country. His important modification of Beckmann's boiling-point method for determining the molecular weights of substances in solution, an account of which appeared in 1892 in tho Journal of the Chemical Society, was a notable contribution to tho practical side of physical chemistry, whilst his work on the molecular conductivity of amidosulphonic acid ( $J$. Chem. Soc., 1896) had an important bearing on the problems of molecular structure and the influence of substituent groups. In this connexion, mention must also bo made of his allied investigations on the constitution of glycocoll and its derivatives, in which he brought forward evidence for the ring- as against the usually accepted chain-structure.

Sakurai was the founder of a great school of chemical research in Japan, many of his pupils, for 
example, Ikeda, Osaka, and Matsubara, becoming themselves university professors and leaders of chemical research. He retired from his University professorship in 1919, having served the cause of science and education for nearly forty years, not only as inspiring teacher and investigator, but also as University councillor, dean of the Faculty of Science, and acting president of the University (elected honorary professor soon after his retiral).

It is not possible to exaggerate the importance of the work which Sakurai did in promoting the establishment and development of great organizations for scientific research in Japan. Indeed, it is only fair to say that the eminent position which that country occupies to.day in the world of pure and applied science is largely due to his initiative, energy, and foresight. Having been for more than thirty years before the outbreak of the Great War one of the most active members of the Tokyo Chemical Society, of which he was several times elected president, the events of 1914-18 convinced him (and others in Japan) that a great development of scientific research was necessary for the well-being, prosperity and safety of that country. The first result of these efforts was the establishment in 1917 of tho important "Institute of Physical and Chemical Research". Not content with this great success, Sakurai, with his colleagues and friends, worked for many years for the establishment of a national organization of much wider scope, which wonld have for its main object the promotion of research in all branches of science. The final result was that, backed by the influence and a splendid gift of H.M. the Emperor, and provided with an ample subsidy voted by the two Houses of the Imperial Diet, the Japaneso Society for the Promotion of Scientific Research, with H.I.H. Prince Chichibu as patron, Viscount Saito (then premier) as president, and Prof. Sakurai as chairman of the Board of Directors, came into existence in 1933.

The labours involved in the accomplishment of these great designs by no means exhaust all that Sakurai did for his country and for science. Ho was elected president of the National Research Council of Japan soon after the international conferences held in 1918 in London and Paris, and retained this position until his death. Ho attended, as the leader of the Japanese delegation, the second Pan-Pacific Science Congress, held in Australia in 1923, and at the third Congress, in Tokyo in 1926, prepared, as chairman of the International Committee, a draft constitution and by-laws for the permanent organization of the Congress. These were adopted with only slight verbal alterations, and the Pan-Pacific Science Association came into existence.

Prof. Sakurai attended, as the scientific representative of his country, very many international meetings and congresses. His dignified bearing, clear. sighted wisdom, and charming personality became in this way widely lnown to men of science of many nations. He was twice elected a vice-president of the International Chemical Union, namely, in 1923 and 1928, and at the third general assembly of the International Council of Scientific Unions (London,
1937), was elected a vice-president, filling the vacancy created by the death of Marconi.

Mrany honours came to Sakurai from foreign countries. Thus he received the honorary degree of LL.D. from the University of Glasgow in 1901, and was elected an honorary member of the Chemical Society of France, the Society of Chemical Industry, the Royal Institution of Great Britain, the American Chemical Society, the Academy of Sciences of the U.S.S.R., and the Chemical Society of Poland. In 1931 he was elected an honorary fellow of the Chemical Society, and in 1937 an honorary fellow of University College, London. This very high distinetion from his old alma mater gavo him particular pleasure.

It was natural and just that the great and meritorious services which he rendered to his country were signalized by distinguished honours : Order of the First Class of the Sacred Treasure (1916); appointed by the throno a member of the House of Peers (1920) and Privy Councillor (1926); Grand Cordon of the Rising Sun (1929). Shortly before his death he received the Grand Cordon of the Rising Sun and Paulownia, and was created a baron*.

Owing to the old connexion of University College, London, with Prof. Sakurai and with the develop. ment of the Empire of Japan as one of the scientific great powers of the world, I had the privilege of welcoming to the Chemical Department of University College a number of Japaneso men of science, including many Ramsay Scholars, amongst whom may bo mentioned K. Matsuno, K. Suzuki, R. Azuma, H. Tsukamoto, Y. Hori, N. Kamoyama, K. Kodama, R. Sato, S. Takagi, Y. Yamaguchi, Mr. Emi, R. Shinoda, Y. Nagai, T. Somiya, I. Sawai, R. Tsuchida, R. Mratsuda, N. Ando, and H. Oosaka. The pleasant and friendly association with these young men, many if not all of whom now occupy important positions in their own country, was a very happy experience in my life; and to have been able to contributo to the preservation of a long and faithful friendship an especial joy.

The name of Joji Sakurai will live in the history of science and civilization. As a great patriot, his name will shine in the history of his country. Joji Sakurai, the man, lives as a fragrant memory in the minds of his host of friends.

F. G. Donnan.

I am deeply indebted to Prof. Koichi Matsubara for much of the biographical information embodied in this notice.

\section{Prof. M. V. Shuleikin}

Soviet science has suffered a great loss in the death on July 17 of Prof. M. V. Shuleikin, member of the Academy of Sciences of the U.S.S.R. and chief engineer of the Department of Communications of the Red Army.

Prof. Shuleiken spent thirty years of strenuous work in the preparation of numerous scientific workers in the field of radio-communications and in the development of Soviet radio-technics. He commenced his scientific and teaching career in 1908 after graduating from the St. Petersburg Polytechnical Institute. Soon after the Revolution he 